\title{
DETERMINANT AGE AT FIRST MARRIAGE AMONG WOMEN IN EAST JAVA
}

\author{
Ali Imron', Siti Maizul Habibah ${ }^{2}$, Udin Kurniawan Aziz ${ }^{3}$ \\ ${ }^{1}$ Social Sciences Education Study Program, Faculty of Social Sciences and Law, State University of Surabaya, 60231 \\ Surabaya, East Java, Indonesia \\ ${ }^{2}$ Pancasila and Civic Education Study Program, Faculty of Social Sciences and Law, State University of Surabaya, 60231 \\ Surabaya, East Java, Indonesia \\ ${ }^{3}$ Training and Development Program, East Java Province National Board of Population and Family Planning, 60282 Surabaya, \\ East Java, Indonesia \\ Corresponding Author: Ali Imron \\ E-mail: aliimron@unesa.ac.id
}

\begin{abstract}
Indonesia is one of the countries with the highest percentage of child marriages in the world (rank 37) and the second highest in ASEAN after Cambodia. Government has issued regulations in order to reduce child marriage rates, however the results are still not significant. Economic, social, and cultural factors are significant factors in child marriage phenomenon. This study aims to analyze the relationship between spouses' age, knowledge of Adolescent Reproductive Health, age when first sexual intercourse happened, education, spouses' education, media exposure, wealth quintile index and the age of first marriage for women in East Java. This study is non-functional research using The Indonesian Demographic and Health Survey 2017 (IDHS) data with a sample size as many as 4,491 women whom got married at 15-24 years old. Data were analyzed using univariate and multivariate techniques. The results of this study prove that the spouses' age, knowledge of Adolescent Reproductive Health, age when first sexual intercourse happened, education, spouses' education, media exposure, wealth quintile index variables are significantly related to the determinants of women's first marriage age in East Java. This study provides recommendations, including revitalizing 8 family functions, strengthening creativity and innovation in the Marriage Age Maturing program, and fostering life skills through training and empowerment programs.
\end{abstract}

Keywords: determinant; first marriage age; East Java

\begin{abstract}
ABSTRAK
Indonesia termasuk negara dengan persentase perkawinanan anak tertinggi di dunia (rangking 37) dan tertinggi kedua di ASEAN setelah Kamboja. Berbagai kebijakan dikeluarkan oleh pemerintah guna menurunkan angka perkawinan anak, namun hasilnya masih belum signifikan. Ekonomi, sosial, dan budaya menjadi faktor signifikan munculnya fenomena perkawinan anak. Penelitian ini bertujuan menganalisis hubungan faktor umur pasangan, pengetahuan Kesehatan Reproduksi Remaja (KRR), umur pertama melakukan hubungan seksual, pendidikan, pendidikan pasangan, keterpaparan media, dan indeks kuintil kekayaan dengan umur kawin pertama (UKP) wanita di Jawa Timur. Penelitian ini merupakan penelitian nonreaksional menggunakan data Survei Demografi dan Kesehatan Indonesia (SDKI) 2017 dengan jumlah sampel adalah 4.491 wanita yang kawin pada usia 15-24 tahun. Data dianalisis dengan menggunakan teknik univariat dan multivariat. Hasil penelitian ini membuktikan bahwa variabel umur pasangan, pengetahuan KRR, umur pertama melakukan hubungan seks, pendidikan, pendidikan pasangan, keterpaparan media, dan indeks kuintil kekayaan berhubungan secara signifikan terhadap determinan UKP wanita di Jawa Timur. Penelitian ini memberikan rekomendasi, antara lain revitalisasi 8 fungsi keluarga, penguatan kreativitas dan inovasi program Pendewasaan Usia Perkawinan (PUP), dan pembinaan life skill melalui program pelatihan dan pemberdayaan.
\end{abstract}

Kata kunci: determinan; usia kawin pertama; Jawa Timur

\section{INTRODUCTION}

Early-age marriage is a common phenomenon in Indonesian society. The prevalence of early-age marriage tends to vary from country to country. The International
Center for Research on Woman (ICRW) states that 51 million young women in 15-19 years old range are married. The United Nations estimates that by 2020 , there will be 140 million young women who are married (Manzahri, 
2016). The Council on Foreign Relations (CFR) study, revealed the reality of early-age marriage found in several regions in the world, such as in South Asia (46.8\%), Sub-Saharan Africa (37.3\%), Latin America (29\%), and East Asia and the Pacific (17.6\%). The phenomenon of early-age marriage generally occurs in many developing countries. Whereas in developed countries such as the United States, Britain, Canada and Austria, only a few cases were found (Addaney and Azubike, 2017).

The percentage of early-age marriage in Indonesia ranked the second highest in ASEAN. Based on IDHS 2017 data, the median of first marriage age for 25-49 years old young women is 20.8 years old. Married women aged $25-49$ is 21.8 years old and married men aged 25-49 are 24.6 years old. Median of first marriage age for 25-49 years old once-married women trends increased from 17.1 years old in the IDHS 1991 to 21.8 years old in the IDHS 2017. Whereas the median of first marriage age for married women aged 25-49 who lived in urban areas was higher (22.9 years old) than those who lived in rural areas (20.9 years old). East Java data shows, the median of first marriage age for women aged $15-19$ is 17 years old, while the median age of first marriage for women aged 20-24 is 22 years old (Central Bureau of Statistics, National Board of Population and Family Planning, Indonesian Ministry of Health, 2017).

National policy through the 2015-2019 National Medium Term Development Plan scheme mandates improving the life quality of Indonesian people through priority agendas in population, family planning, and family development. Population development and family planning is directed at improving the equitable access and quality of family planning services in each region and community groups through strategies to increase knowledge and understanding of reproductive health for adolescents in the education space and socialization of maturity age of marriage and preparation of family life (Nalle and Kiha, 2018).

Based on the 2015-2019 National Board of Population and Family Planning Strategic Plan as outlined in the Regulation of the Head of National Board of Population and Family Planning Number 199 Year 2016, it was stated that the median target of women's first marriage age in 2015-2019 is 21 years old, while the target in 2017 is 20.8 years old and in 2018 is
20.9 years old. However, to achieve the median target of the married age for 21 years old until the end of 2019 still requires hard work. Especially when faced with the ideal age of marriage is 21 years old for women and 25 years old for men. Moreover, in the 2019 Government Work Plan (GWP), one of the objectives is to improve adolescent reproductive health development in the framework of (maturity age of marriage) and Family Life Preparation for Youth through the Youth Information and Counseling Center and Youth Family Development.

The high number of early-age marriage practices is caused by several factors. Based on the analysis of the 2016 Susenas Data, it is stated that the factors used in analyzing earlyage marriages, such as women's education (children marriages); women's occupation (informal sector); access to information (in a positive sense); and women's residential area are proved to significantly influence the probability of early-age marriage. Based on 2016 Susenas Data, there are nine out of ten lowly-educated young women who are married. Women with low education are 4.43 times more likely to marry at early age than those with higher education. Economic factors (occupation) is quite influential on early-age marriage occurence (Imron, Sjafii, and Mentari, 2018).

Early-age marriage phenomenon is mostly influenced by socio-cultural construction factors. In socio-cultural terms, Bangkalan society generally assumes that a woman must be married immediately with the reason to save the family's dignity. The patriarchal culture which is very strong in the form of discrimination and practices of violence, further perpetuates the practice of early marriage (Imron, Sjafii, and Mentari, 2018).

Imron's research revealed the factors that cause women to marry at an early age include social and cultural factors (matchmaking and value construction), economic factors (a daughter is a family burden, getting new labor), and personal factors (Imron, Sjafii, and Mentari, 2018).

In addition, knowledge about family life is still low. Study by Ma'arif (2018) stated that young people who did not have enough knowledge about family life caused them to make wrong decisions, including getting married at an early age. In fact, adolescents are 
facing vulnerable exposure to reproductive health risks (Fajriyah, 2008).

The majority of previous studies discuss the factors that influence the practice of earlyage marriage in general, but there has no specific analysis on the first marriage age. Therefore, research to analyze the first marriage age in East Java is explorable. The data used are respondents who have entered the Indonesia Demographic and Health Survey in 2017.

The purpose of this research is to analyze the relationship between spouse's age, reproductive health knowledge, age when the first sexual intercourse happened, education, spouse's education, media exposure, wealth quintile index factors and women's first marriage age (between 15-24 years old) in East Java based on the Indonesian Health Demographic Survey 2017 (IDHS).

\section{METHODS}

This research is a non-functional study using the IDHS 2017 data. The analysis of this study focused on women who were married for the first time at the age of 15-24 years old in East Java. The IDHS 2017 data sources used in this study came from the Woman of Childbearing Age module. The sample used in this study was women aged 15-49 who were married and first married at 15-24 years old (N = 4491).

This study uses the independent variable and the dependent variable. Independent variables consist of spouse's age, reproductive health knowledge, age when first sexual intercourse happened, education, spouse's education, media exposure (intensity of exposure to information sources from newspapers/magazines, radio and television) and wealth quintile index. Whereas dependent variable is women's first marriage age around 15-24 years old. This research uses univariate and multivariate data analysis. Multinominal logistic regression test on the independent variables on the dependent variable.

\section{RESULT}

\section{Women's First Marriage Age of 15-24 Years Old}

Figure 1 shows the distribution of the women's first marriage aged 15-24. As many as $55.9 \%$ of women in East Java were married between 15-19 years old. While women who married between 20-24 years old were $44.1 \%$. In addition, Figure 1 also shows the median of women's first marriage age are around 15-24 years old. The median for first marriage age between 15-19 years old is 17 years old, while the median for the first marriage age between 20-24 years old is 20 years old.

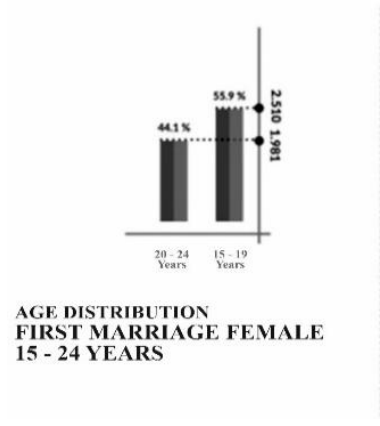

MEDIAN 15 - 24 YEARS

Figure 1. Age Distribution and Median Women's First Marriage Age 1524 Years Old

\section{Demographic Factors Related to Women's First Marriage Age of 15-24 Years Old}

Spouse's Age

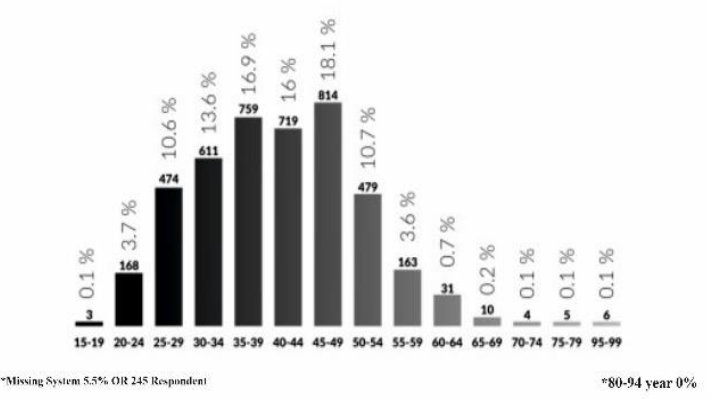

Figure 2. Spouse's Age

Figure 2 shows the age distribution of women's first marriage age 15-24 years old. As many as $18.1 \%$ of middle-aged couples (adults) in the age range 45-49 years old, while in the age range 40-44 years old (16\%) and the age range of 35-39 years old is as many as $16.9 \%$. These findings describe that the majority of women who, when married for the first time aged 15-24, prefer to marry men who are above it, compared to men of the same age as them.

\section{Adolescent Reproductive Health Knowledge}

Respondents' knowledge about reproductive health showed good result. There 
is sufficient understanding towards reproductive health related to kinds of Sexually Transmitted Infection. Despite $3.6 \%$ of respondents stated that they do not know about reproductive health, the findings described that women whom married at 15-24 years old have already acquired sophisticated knowledge about reproductive health.

\section{Age when First Sexual Intercourse Happened}

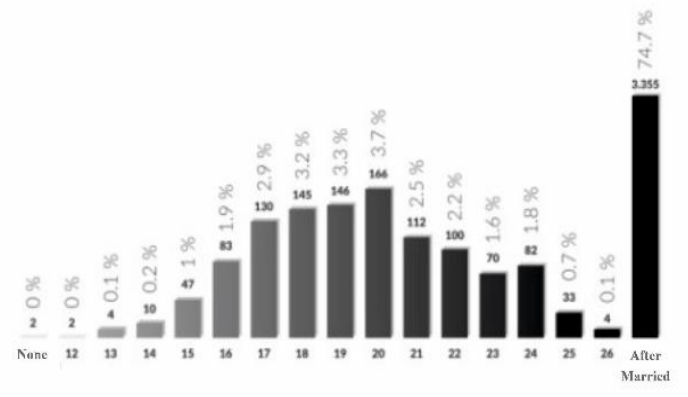

Figure 3. Age when First Sexual Intercourse Happened

Although respondents married at young age, but sexual intercourse was first done after marriage, not before. This condition shows that $74.7 \%$ of respondents had sexual intercourse after marriage.

\section{Social Factors Related to Women's First Marriage Age at 15-24 Years Old}

\section{Education}

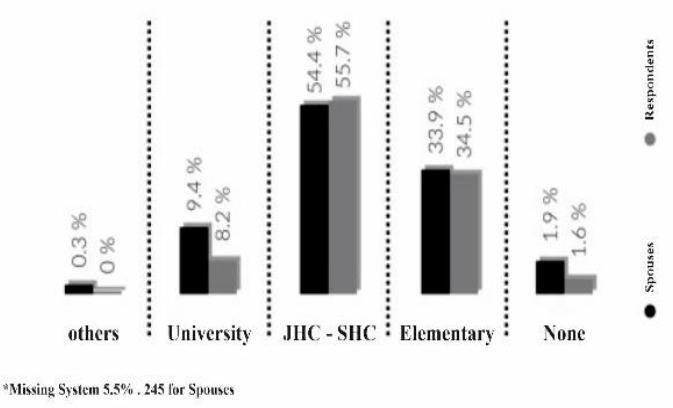

Figure 4. Respondents and Spouses' Level of Education

Figure 4 shows the educational level of respondents, namely women who were married for the first time at the age of 15-24 years old, where $55.7 \%$ of respondents had a junior-high school education and only $8.2 \%$ had higher education up to tertiary level. On the other hand, there are $1.6 \%$ of respondents who never had formal education.

\section{Spouses'Education}

Coherently with respondents' education, educational level of the spouses/husbands was also low, where $51.7 \%$ only had junior highschool education, $32.1 \%$ had elementary school education, and $1.8 \%$ never had education at all. Although as many as $8.9 \%$ had higher education and $0.3 \%$ had other education.

\section{Media Exposure}

As many as $75 \%$ of respondents claimed to have never read a newspaper/magazine, while $19.2 \%$ read newspaper less than once a week and $5.8 \%$ read a newspaper/magazine once a week. This findings reinforce that printed media in the form of newspapers/magazines are progressively abandoned by the public, especially respondents who are married for the first time at $15-24$ years old.

Regarding the intensity of listening to the radio, as many as $64.3 \%$ of respondents claimed to have never listened to the radio, while $19.3 \%$ of them listen to the radio less than once a week. Another $16.3 \%$ listen to the radio once a week, and $0.1 \%$ listen to other media.

Regarding the intensity of watching television shows, $21 \%$ of respondents claimed to have never watched television and $11.1 \%$ watched television less than once a week. An interesting finding is that $86.6 \%$ of respondents access television once a week and $0.1 \%$ access other media. Related to the high access to electronic media, such as television and the internet will open up respondents' opportunities to get various types of information.

\section{Economic Factors}

Quintile Wealth Index

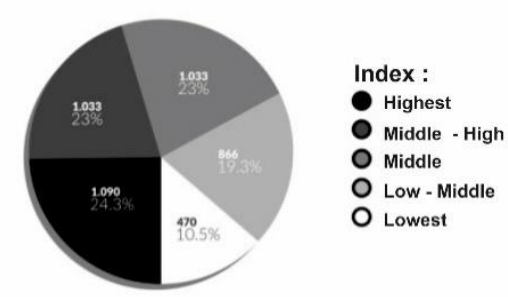

Figure 5. Quintile Wealth Index

Figure 5 shows that $24.3 \%$ are in the top quintile category, $23 \%$ of the middle to upper quintile and $23 \%$ of the middle quintile category. While the lower middle quintile is $19.3 \%$ and the lowest quintile is $10.5 \%$. These 
Table 1. Multinominal Logistic Regression Analysis

\begin{tabular}{|c|c|c|c|c|c|c|c|}
\hline \multirow{2}{*}{ Variable } & \multirow{2}{*}{ ME } & \multirow{2}{*}{ Robust SE } & \multirow{2}{*}{$\mathbf{Z}$} & \multirow{2}{*}{ P-value } & \multicolumn{2}{|c|}{$95 \% \mathrm{CI}$} & \multirow{2}{*}{ Information } \\
\hline & & & & & Lower & Upper & \\
\hline Spouse's Age & -0.001 & 0.016 & -2.24 & 0.422 & 0.971 & 1.004 & Related \\
\hline $\begin{array}{l}\text { Reproductive } \\
\text { Health } \\
\text { Knowledge }\end{array}$ & -0.003 & 0.085 & -2.802 & 0.034 & 0.482 & 2.145 & Related \\
\hline $\begin{array}{l}\text { Age when the } \\
\text { first sexual } \\
\text { intercourse } \\
\text { happened }\end{array}$ & -0.030 & 0.114 & -2.90 & 0.012 & 0.931 & 0.995 & Related \\
\hline Education & -16.723 & 0.510 & 2.74 & 0.000 & 0.123 & 2.611 & Related \\
\hline $\begin{array}{l}\text { Spouse's } \\
\text { Education }\end{array}$ & 15.787 & 1.396 & 2.55 & 0.000 & & & Related \\
\hline $\begin{array}{l}\text { Media } \\
\text { Exposure }\end{array}$ & 0.436 & 0.381 & -1.05 & 0.06 & 0.922 & 5.437 & Related \\
\hline $\begin{array}{l}\text { Wealth } \\
\text { Quintile Index }\end{array}$ & -1.474 & 0.207 & -7.49 & 0.000 & 5.702 & 23.313 & Related \\
\hline
\end{tabular}

findings describe that women who get married for the first time at 15-24 years old have economic status in the top quintile. This condition is contrary to various studies that show that women at 15-24 years old who had early-age marriage in the economic background of poor families.

\section{Multinomial Logistic Regression Analysis of Determinants of Women's First Marriage Age of 15-24 Years Old}

To define the determinants for women's first marriage age of 15-24 years old in East Java, this study used Multinominal Logistic Regression analysis with the help of the STATA 13. The analysis is illustrated in Table 1.

Table 1 shows the results of the regression analysis to prove that the variables namely spouse's age, reproductive health knowledge, age when the first sexual intercourse happened, education, spouse's education, media exposure, and wealth quintile index are significantly related to the determinants for women's first marriage age of 15-24 years old in East Java.

\section{DISCUSSION}

\section{Women's First Marriage Age of 15-24 Years Old}

Women in East Java chose to marry underages (under 18 years). This condition showed that children marriage in East Java is still high by $55.9 \%$. Though a marriage aimed at realizing a happy and prosperous family life requires maturity, especially the psychological maturity of each partner. Psychological maturity is closely related to age. For couples who are married underages do not fully understand their rights and obligations in the household because there is no physical or mental maturity of one or both (Central Bureau of Statistics and UNICEF Indonesia, 2016).

Study conducted by Imron, Sjafii and Mentari (2018) showed the same conditions that women who marry at the very young age will have a psychological impact, including frequent disputes and domestic violence, wife's unpreparedness to face a double burden; difficulty adapting to changes (maladjustments), emotional instability in resolving family conflicts, and the maternal depression from unpreparedness to raise children.

Similar conditions also occur in several other developing countries. In Thailand for example, study by Triyono (2016) showed that children marriage also happen in Thailand. A total of 1,100 female teenagers in Thailand gave birth in 2016. The same conditions also occur in India where there were as many as $40 \%$ of underage marriages. Underage marriages in India are related to tradition and culture, making it difficult to change (Asmarita, 2015).

When compared with other studies, the number of underage marriages in East Java is higher than studies in Thailand and India. This is due to underage marriage management programs, such as the Generasi Planning 
(GenRe) program that has not been running optimally. This condition is illustrated by the underage marriage age range of 10-19 years old which is still high (47.50\%), information exposure on Adolescent Reproductive Health is still low (24.70\%), Fostering Teen Family information exposure is still low $(25.60 \%)$. Likewise, information exposure on PIK Adolescents/Students is still low, at $11 \%$ (Rini and Tjadikijanto, 2018).

\section{Demographic Factors Related to Women's First Marriage Age of 15-24 Years Old}

\section{Spouse's Age}

Studies in East Java showed that younger women prefer to marry older men. As many as $18.1 \%$ middle-aged couples (adults) in the age range of 45-49 years old, while in the age range of 40-44 years old were $16 \%$ and thr age range of 35-39 years old were as many as $16.9 \%$.

One of them was due to the inherent social and cultural construction in society that women are better off marrying men who are older and certainly more established, especially economically (Abel, E. L. - Kruger, 2008). The community actually gives a negative assessment to women who marry younger men. Marriages with age differences are prone to conflict. Conflicts that can occur are economic and communication problems. Women assume that older men will try to find younger women to marry (Warren, 1996).

\section{Adolescent Reproductive Health Knowledge}

One of Adolescent Reproductive Health's knowledge is changes in body shape. Associated with changes in body shape, study by Artaria (2012) explained that the weight of men and women is significantly different in all age groups, where women experience growth spurt. With the purpose of the socialization of knowledge about the differences between men and women regarding the shape and function of the body begins at a slower age in boys. At the age of 12 , girls begin to experience changes in their bodies due to growth spurt. At the age of 12 years there is also an increase in interest in the opposite sex (Haroian, 2000).

Studies in East Java showed that the knowledge of Adolescent Reproductive Health is relatively very good, as many as $90 \%$ understand reproductive health (Central Bureau of Statistics, National Board of Population and
Family Planning, Indonesian Ministry of Health, 2017). Condition in East Java was still better compared to Central Java. Another study provided the result that one of the factors related to adolescent sexual behavior in Central Java was knowledge of reproductive health. This finding proved that the knowledge of adolescents in Central Java about reproductive health was still very low, i.e., more than $75 \%$ of respondents did not understand about reproductive health (Suryoputro, Ford, and Shaluhiyah, 2006).

\section{Age when First Sexual Intercourse Happened}

The majority of women whom first married at 15-24 years old in East Java, are still hold social values and norms that place religious and moral norms as a foundation in social interaction. Even so, $0.3 \%$ of women have had sexual intercourse for the first time before marriage, at the age of $12-14$. This condition is in line with research by Rahadi and Sofwan (2017) which explained that women in Semarang aged under 18 years old $(56 \%)$ were having their first sexual intercourse.

\section{Social Factors Related to Women's First Marriage Age 15-24 Years Old}

\section{Education and Couples' Education}

Referring to Regulation Number 20 Year 2003 concerning National Education System, Article 6 Paragraph (1) which states, "Every citizen aged seven to fifteen years is required to attend basic education". In East Java, 55.7\% of respondents junior high-school education, while $51.7 \%$ partner education received juniorhigh school education

Education can influence a woman to delay the age of her marriage. The longer a woman attends school education, the higher the theoretical age of her first marriage. The majority of women in Malang who took education at the elementary level $(70.27 \%)$ married at a young age (Kurniawati, Nurrochmah, and Katmawanti, 2017).

\section{Media Exposure}

On the current era of globalization and modernization, the choice of media has shifted to the types of electronic or digital media. This finding also reinforces the assumption that radio media has begun to be abandoned by the public. Computerization and digitalization are 
becoming choices in accessing various information. Related to the high access to electronic media, such as television and the internet will open up opportunities to get various types of information.

Yutifa, Dewi, and Misrawati (2015) revealed that the internet is the main trigger for adolescent sexual behavior, both at risk and not at risk. The results showed there is a relationship between e-media and adolescent sexual behavior in Pekanbaru. Teenagers/adolescents with no risk sexual behavior using internet were as many as $32.1 \%$. Likewise, adolescents with risky sexual behavior using the internet were as many as $67.9 \%$.

The most exposure to pornographic media are through mobile videos and social media. Teenagers tend to imitate what they have seen without filtering. The development of the media does not always have a good impact on adolescents. Freedom of access to information can influence the actions of adolescents. Media that contains pornography can affect underage marriages. Research data in Sambas showed that adolescents who are exposed to pornographic media tend to do underage marriage (72.72\%) compared to those who are not which is $27.27 \%$ (Aulia, Taufik and Hastuti, 2014).

\section{Economic Factors}

\section{Wealth Quintile Index}

The findings of the data actually contradict the various studies that show that marriage children have a poor family economic background. Various studies actually showed that the economic status of the family has a significant influence on early-age marriage motives. Economic status is related to the level of education of adolescents. Inability of parents to afford their children's education so they have to drop out of school and choose to let their children married (Sarwoprasodjo, 2014).

The economic factors that cause children marriage are in line with the growing construction in society that girls are the family's economic capital, where girls are expected to raise the family's economic degree. One of them is to get married at an early age. Research by Toraja (2009), also stated the same findings, where adolescents wished to help the family economy. This is related to the desire to get married soon.

\section{CONCLUSIONS AND SUGGESTIONS}

\section{Conclusion}

The results of this study prove that the variable age of the couple, Adolescent Reproductive Health knowledge, age at first sex, education, partner education, media exposure, and wealth quintile index are significantly related to the determinants of the age of first marriage of women 15-24 years in East Java.

\section{Suggestion}

Based on the results of the study, several recommendations can be formulated. First, rthe revitalization of 8 (eight) family functions as the foundation in carrying out family life. Second, strengthening creativity and innovation in the maturity age of marriage program based on needs, characteristics of the target area, and based on data from study results. Third, enhancement the quality of human resources in the form of fostering life skills through training and empowerment programs.

\section{REFERENCES}

Abel , E . L . - Kruger, M.. L.., 2008. Az életkori heterogámia és az élettar- tam a házasságokban: bizonyítékok a zsidó és keresztény temetôkbôl (Age Heterogamy and Longevity: Evidence from Jewish and Christian Cemeteries.). pp.1112-1113.

Addaney, M. and Azubike, O., 2017. Education as a Contrivance to Ending Child Marriage in Africa: Perspectives from Nigeria and Uganda. Amsterdam Law Forum, 2(9), pp.110-130.

Artaria, M.D., 2009. Perbedaan antara Laki-laki dan Perempuan: Penelitian Antropometris pada Anak-Anak Umur 6-19 Tahun. Jurnal Masyarakat Kebudayaan dan Politik, 22(4), pp.343-349.

Asmarita, 2015. Peran Unicef dalam Menangani Kasus Pernikahan Anak di Bawah Umur di India. Journal of Chemical Information and Modeling, 53(9), pp.1689-1699.

Aulia, A., Taufik, M. and Hastuti, L., 2014. Faktor-faktor yang Mempengaruhi Perkawinan Usia Muda pada Remaja Putri Usia 10-19 Tahun di Selakau Sambas. Jurnal Mahasiswa dan Peneliti Kesehatan, 2(4), pp.41-53. 
Central Bureau of Statistics, National Board of Population and Family Planning, Indonesian Ministry of Health, 2017. Survei Demografi dan Kesehatan. Jakarta.

Central Bureau of Statistics and UNICEF Indonesia, 2016. Kemajuan yang Tertunda: Analisis Data Perkawinan Usia Anak di Indonesia. Jakarta.

Fajriyah, N., 2008. Keinginan Menggunakan Metode Kontrasepsi pada Remaja di Masa Mendatang di Provinsi Jawa Timur. Jurnal Biometrika dan Kependudukan, 6(2), pp.163-170.

Haroian, L., 2000. Child Sexual Development. Electronic Journal of Human Sexuallity, 3(1), pp.85-93.

Imron, A., Sjafii, A. and Mentari, D., 2018. Dampak Pernikahan Anak terhadap Kuantitas dan Kualitas Penduduk di Jawa Timur. Surabaya: Perwakilan BKKBN Provinsi Jawa Timur.

Kurniawati, L., Nurrochmah, S. and Katmawanti, S., 2017. Hubungan antara Tingkat Pendidikan, Status Pekerjaan dan Tingkat Pendapatan dengan Usia Perkawinan Pertama Wanita di Kelurahan Kota Lama, Kecamatan Kedungkandang Kota Malang. Jurnal Preventia, 2(1), pp.110.

Ma'arif, 2018. Hubungan antara Tingkat Pengetahuan dan Sosial Budaya dengan Sikap Remaja Terkait Pendewasaan Usia Perkawinan. Jurnal Biometrika dan Kependudukan, 7(1), pp.39-48.

Manzahri, M., 2016. Hubungan Status Sosial dengan Pernikahan Usia Dini. Jurnal Ilmiah Kesehatan, 5(10), pp.676-688.

Nalle, F.W. and Kiha, E.K., 2018. Analisis Faktor-faktor yang Mempengaruhi Tingkat Kemiskinan di Kecamatan Insana
Kabupaten Timor Tengah Utara. Jurnal Dinamika Ekonomi Pembangunan, 1(2), pp.71-81.

Rahadi, D.S. and Sofwan, I., 2017. Perilaku Seks Bebas pada Anggta Club Motor X Kota Semarang Tahun 2017. Jurnal of Healt Education, 2(2), pp.115-121.

Rini, I.M. and Tjadikijanto, Y.D., 2018. Gambaran Program Generasi Berencana (GenRe) di Indonesia dan di Provinsi Jawa Timur Tahun 2017. Jurnal Biometrika dan Kependudukan, 7(2), pp.168-177.

Sarwoprasodjo, S., 2014. Pengaruh Status Ekonomi Keluarga Terhadap Motif Menikah Usia Dini. Sodality: Jurnal Sosiologi Pedesaan, 2(1), pp.53-62.

Suryoputro, A., Ford, N.J. and Shaluhiyah, Z., 2006. Faktor-Faktor yang Mempengaruhi Perilaku Seksual dan Layanan Kesehatan Seksual dan Reproduksi. Makara, Kesehatan, 10(1), pp.29-40.

Toraja, K.T., 2009. Kebiasaan Pernikahan Usia. Jurnal MKMI, 5(4), pp.89-94.

Triyono, N., 2016. Isu Perkawinan Minoritas di Thailand. De Jure: Jurnal Hukum dan Syari'ah, 8(1), pp.38-47.

Undang-Undang Republik Indonesia Nomor 20 Tahun 2003 Tentang Sistem Pendidikan Nasional. Jakarta: Presiden Republik Indonesia.

Warren, C.A.B., 1996. Older Women, Younger Men : Self and Stigma in Age-Discrepant Relationships. Clinical Sociology Review, 14(1), pp. 62-86.

Yutifa, H., Dewi, A.P. and Misrawati, 2015. Hubungan Paparan Pornografi Melalui Elektronik Terhadap Perilaku Seksual Remaja. JOM, 2(2), pp.1141-1148. 